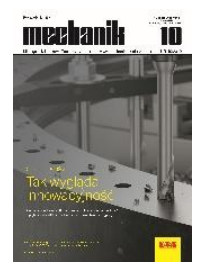

\author{
How to cite this article: \\ Authors: Kamila Wilkońska, Agata Biniek, Daniel Grochala, Mirosław Pajor \\ Title of article: „Impact of used semi-finished products on the cost of mass production of the part in the automotive in- \\ dustry" \\ Mechanik, No. 10 (2019) \\ DOI: https://doi.org/10.17814/mechanik.2019.10.90
}

\title{
Impact of used semi-finished products on the cost of mass production of the part in the automotive industry
}

\author{
KAMILA WILKOŃSKA \\ AGATA BINIEK \\ DANIEL GROCHAŁA \\ MIROSŁAW PAJOR *
}

\begin{abstract}
Inż. Kamila Wilkońska (kamila.wilkońska@zut.edu.pl) - Zachodniopomorski Uniwersytet Technologiczny w Szczecinie, Szczecin, Polska Mgr inż. Agata Biniek, agata.biniek@zut.edu.pl, https://orcid.org/0000-0002-8676-5607 - Zachodniopomorski Uniwersytet Technologiczny w Szczecinie, Szczecin, Polska

Dr inż. Daniel Grochała, daniel.grochała@zut.edu.pl, https://orcid.org/0000-0003-2553-7739 - Zachodniopomorski Uniwersytet Technologiczny w Szczecinie, Szczecin, Polska

Dr hab. inż. Mirosław Pajor, prof. ZUT, miroslaw.pajor@zut.edu.pl, https://orcid.org/0000-0002-7701-385X - Zachodniopomorski Uniwersytet Technologiczny w Szczecinie, Szczecin, Polska
\end{abstract}

The article deals with the problem of determining production costs when designing part technology for the automotive industry. In mass-production and mass production, several variants of production processes are usually prepared, which are then assessed in economic and technological terms. Technological variants most often differ in the type of semi-finished product used, which significantly affects the efficiency and cost of machining carried out in subsequent operations. The article attempts to determine the methodology of determining costs for the developed technological variants. Simulation tests were carried out on production processes based on commercial semi-finished products and involving machining with high energy absorption, as well as processes based on special semi-finished products and using high-performance machining, characterized by low material consumption.

KEYWORDS: technology of machine parts, machining, rough materials, serial production, cost production, automotive industry

\section{Introduction}

Semi-finished products are an important component of the price of manufactured machine parts. However, at the stage of selecting a blank, it is difficult to determine the costs of the entire production process. Similarly, it is difficult to estimate the costs of preparing a blank (casting, forgings) without full information about the planned machining. The type of the blank influences the machining process, which in turn determines the technical conditions for the production of the blank. When designing a technological process, it is not possible to determine the full cost structure, taking into account the dimensional and shape accuracy of the blank and the required accuracy of the manufactured part [1].

Technologists, who design the production process focus mainly on technological aspects, while they pay less attention to economic issues. However, when they look at production costs, they primarily analyze the costs associated with the selection of machinery and tooling, not the semi-finished product. Meanwhile, the development of an optimal technological process that ensures obtaining the product of the required quality at the lowest possible cost of its production requires that the designed technology and related costs be treated equally. This approach also requires validation. This can be seen in modern production companies, where a specialist from the controlling department joins the constructor-technologist team, who cares about the economics of the process. Most often, this takes place in the next phase of work on technological documentation (pre-prepared technological documentation, including construction and qualitative documentation of the blank). A specialist with knowledge about the economic realities of the company's operation is a great support in the search for the most advantageous production variants.

Currently, in the era of production globalization, there are many suppliers on the market specialized in the production of specific semi-finished products. In the case of light metal parts produced for the needs of the automotive industry, semi-finished products in the form of castings, forgings and extruded profiles are generally used [2]. Due to semi-finished products, the demand for materials can be reduced by up to $90 \%$, as well as the scope of performed machining operations can be significantly reduced. In this way, technology becomes less 
energy-consuming. The possibility of using special blanks depends on the complexity of the geometry and requirements regarding the dimensional and shape accuracy of the final products [2].

\section{Experimental research}

The main goal of the authors was to conduct simulation tests, based on which the impact of the used blank on the economics of the entire production process will be estimated. The modeling of costs includes fixed and variable components, depending on the type of semi-finished product used [3].

The experimental tests were carried out for the production process of aluminum pistons used in the assembly of the main brake valve of the pneumatic braking system in trucks and buses (fig. 1). This is a new project, the period of which has been initially set at five years. The total order volume is expected to be around 1.5 million pieces, delivered in batches of 5,000. The assumed defectiveness of the production process should not be higher than $1.5 \%$ of the production batch size.

For the needs of the project, a new machine tool is planned to be purchased, the base price of which was set at PLZ 600,000. Production costs also include the monthly depreciation value determined by the linear method [4].

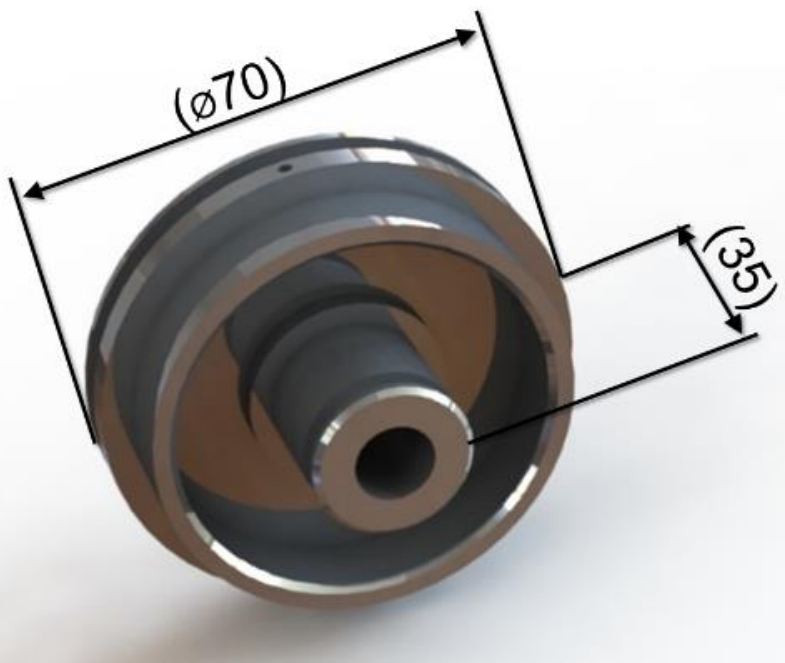

Fig. 1. Piston used in research

The object used to study the economics of production was characterized by free tolerance. The functional dimensions of diameters and positions of the air flow control channels were in IT6 accuracy class, and the tolerances of other machined surfaces - in classes IT9 to IT12. For other dimensions, deviations were determined in accordance with PN-EN 22768-1 [5]. Surface roughness defined in accordance with PN-EN ISO 1302 [6] was in the range of APA $R a 1.6 \div$ APA $R a 3.2$.

Two variants of the technological process were adopted for testing production costs (tab. I).

The first variant assumed the use of semi-finished products in the form of commonly available aluminum bars AlCu4MgSi (A), which after delivery to the plant were cut by the operator with a band saw into discs weighing $415.63 \mathrm{~g}$. At the turning center DMG CTX 310 ECO, turning was carried out in two fastenings on all surfaces until the desired dimensions and shape are obtained. Ten operations were performed in the first fixation and four operations after changing the fixation. During turning operations, $319.8 \mathrm{~g}$ of material were removed. Finally, after CNC machining, the weight of the finished product was $95.83 \mathrm{~g}$.

In the second variant, the equivalent of $\mathrm{AlCu} 4 \mathrm{MgSi}(\mathrm{A})$ aluminum alloy was used in medium processed form i.e. pressure casting. The designed semi-finished product in the form of a cast preparation (including allowances and castings) had a mass of $162.88 \mathrm{~g}$. Dimensional accuracy of the casting allowed to skip dimension machining in IT12 class and partial machining of selected surfaces in IT9 class. In this case, the machining process, carried out on the DMG CTX 310 ECO machine tool, also took place in two fixations. All functional surfaces tolerated in IT6 class were machined on the lathe. Eight treatments were performed in the first fixation, and four treatments after changing the fixation. As a result of processing, $67.76 \mathrm{~g}$ of casting material were turned into chips. The final mass of the finished product was $95.12 \mathrm{~g}$. 
TABLE I. Framework plan of the technological process

\begin{tabular}{|c|c|c|}
\hline Operation number & $\begin{array}{c}\text { AlCu4MgSi(A) } \\
\text { in the rod form }\end{array}$ & $\begin{array}{c}\text { Operation name } \\
\text { in the casting form }\end{array}$ \\
\hline 10 & Cut the rod & CNC machining with change of clamping \\
\hline 20 & CNC machining with change of clamping & Wash \\
\hline 40 & Wash & Control \\
\hline 50 & Control & Pack \\
\hline
\end{tabular}

In both machining processes, the technological values of the finishing parameters were the same. The labor intensity determined on the basis of technological documentation is presented in tab. II. Comparing both cases, the volume difference of the material being cut was $79 \%$.

TABLE II. The evaluated time components on the basis of the work consumption for the technological operation

\begin{tabular}{|lcc} 
Production time components & $\begin{array}{c}\text { AlCu4MgSi(A) } \\
\text { in the rod form }\end{array}$ & $\begin{array}{c}\text { AlCu4MgS } \\
\text { in the casting }\end{array}$ \\
\hline Main time tg [s] & 80 & 21.95 \\
\hline Auxiliary time tp [s] & 22 & 22 \\
\hline Supplementary time tu [s] & 12 & 12 \\
\hline Production time tw $[\mathrm{s}]$ & 114.63 & 55.95
\end{tabular}

The cost of materials was determined on the basis of machining demand. The study of costs was based on raw material prices based on prices from the London Stock Exchange on May 2, 2019 - then one ton of material reached USD 1,818.25 (fig. 2).

ALUMINUM alloy purchase

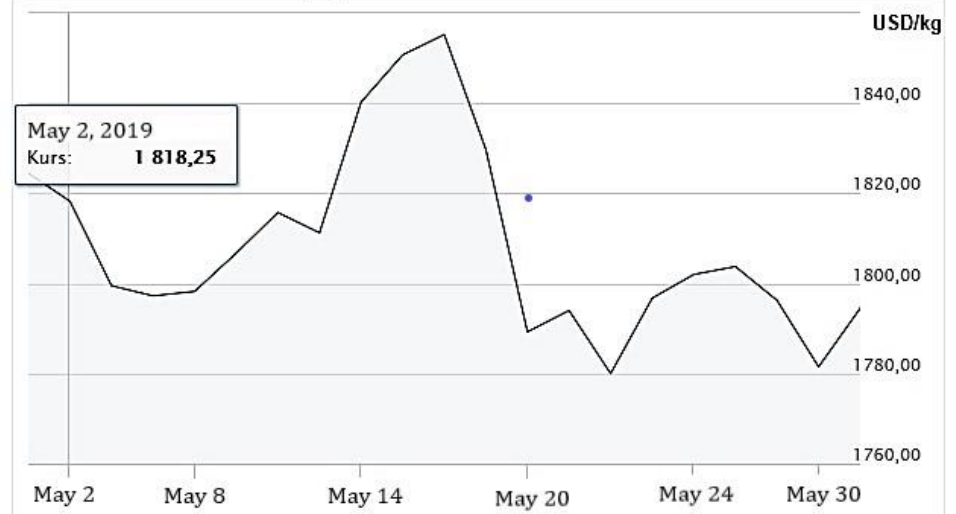

Fig. 2. Aluminum prices quotations in a monthly period [7]

The cost of materials was converted from US dollars to PLZ according to the average exchange rate of the National Bank of Poland (3.82), applicable on May 2, 2019. The calculated price of one kilogram of aluminum alloy in production cost analyses was PLZ 6.95.

The price of processing aluminum goose into the form of a finished cast using standard casting techniques can be estimated after the initial assignment of the preparation to one of three groups. Classification groups are most often defined on the basis of the casting technique used and the technological level of the foundry. There are the following:

- low casting processing (in simple sand forms) - the price of one kilogram of casting should not exceed $30 \%$ of the price of the raw material,

- medium processing in complex sand forms and uncomplicated permanent forms - the price of one kilogram of the cast is usually increased by $30 \div 300 \%$ of the price of the raw material (depending on the cost of making the mold),

- high processing, usually in permanent forms by pressure and centrifugal casting - the price of casting can significantly exceed $300 \%$ of the purchase price of the raw material.

However, it should be remembered that the prices of castings can in any case be significantly reduced using the so-called multi-cavity molds [8]. 
In the cost calculations, semi-processed semi-finished products in the form of castings from a multi-nest (uncomplicated - without cores) mold were used. Castings were created by pressure casting. For this reason, the price of the raw material was increased by additional $30 \%$.

The list of designated material prices is presented in tab. III.

To calculate the productivity of both processes, the machine availability time per one shift was assumed: $7 \mathrm{~h}^{2} 5^{\prime}$ (in accordance with norm VDI 3423) [9]. On this basis, the number of manufactured products was calculated: 227 pieces / shift - in the case of turning from discs, 466 pieces / shift - in the case of machining of castings.

TABLE III. The calculated material consumption and the cost of the semi-finished products used

\begin{tabular}{|l|c|c|}
\hline & Rod & Cast \\
\hline Mass of preform[g] & 415.63 & 162.88 \\
\hline Series size [szt.] & 5000 & 5000 \\
\hline Mass of raw material [kg] & 2078.15 & 814.40 \\
\hline Price for material [PLN/kg] & 6.95 & 6.95 \\
\hline Price of material in series[PLN] & 14443.14 & 7358.10
\end{tabular}

To produce a series in a two-shift system, the first variant requires 176 hours of lathe operation, and in the second variant - 86 hours.

After determining the material costs and the cost of purchasing the machine tool as well as the work involved in the process, the cost of producing a single piston was determined: PLZ 13.27/item for a semi-finished product in the form of a bar and PLZ 6.65/item for casting.

The price of a single piston in the case of production from casting is half as much as in the case of standard rods that are cut into rings - this is the effect of twice the machining time. As it can be seen, this is the factor determining the unit cost of production. Production costs in one shift in both variants are very similar, but the number of manufactured products differs twice.

\section{Summary and conclusions}

Selection of appropriate technology and tooling for waste machining is one of the most important aspects of implementing the new projects in the automotive industry, which requires ensuring high geometric accuracy of manufactured products. This makes technologists focus on finding new machines and tools that meet stringent requirements, while forgetting about the impact of used semi-finished products on final production costs. In addition, it should be noted that for new projects, the costs of their implementation are often estimated without taking into account the long-term perspective.

Based on the conducted research, it can be stated that if a given technology, specific tooling and material are used, the production time of a single part can be significantly shortened, and the efficiency and availability of machines can be increased (and thus more pieces can be produced) if the semi-finished product is selected appropriately.

In some situations, it seems justified to use special semi-finished products, made e.g. in SLM (selective laser melting) or SLS (selective laser sintering) technology, which are still currently relatively expensive.

\section{REFERENCES}

[1] Fiorentino A. "Cost drivers-based method for machining and assembly costestimations in mould manufacturing". International Journal of Advanced Manufacturing Technology. 70, 5-7 (2014): 1437-1444.

[2] Feld M. „Podstawy projektowania procesów technologicznych typowych części maszyn”. Wydanie 3. Warszawa: Wydawnictwa Naukowo-Techniczne, 2003.

[3] Sobczyk G. „Ekonomika małych przedsiębiorstw”. Warszawa: Difin, 2004.

[4] Skoczylas K. „Amortyzacja operacyjnych aktywów trwałych w koszcie wytworzenia”. Autobusy. 12 (2016): $1850-1852$.

[5] PN-EN 22768-1:1999 Tolerancje ogólne - Tolerancje wymiarów liniowych i kątowych bez indywidualnych oznaczeń tolerancji.

[6] PN-EN ISO 1302:2004 Specyfikacje geometrii wyrobów (GPS) - Oznaczanie struktury geometrycznej powierzchni w dokumentacji technicznej wyrobu.

[7] https://www.bankier.pl/inwestowanie/profile/quote.html?symbol=ALUMINIUM (dostęp: 05.06.2019 r.).

[8] Perzyk M. „Odlewnictwo”. Warszawa: Wydawnictwa Naukowo-Techniczne, 2000.

[9] VDI 3423:2011 Technical availability of machines and production lines. Terms and definitions, determination of time periods and calculation. 